\title{
Social Housing between Theory and Implementation Comparative Analytical Study
}

\author{
Ahmed Abdul Moanem Al Qattan* \\ Department of Architecture - Faculty of Engineering - Al-Azhar University - Nasr City - Cairo- Egypt \\ Received 02 Sept 2019, Accepted 03 Nov 2019, Available online 05 Nov 2019, Vol.9, No.6 (Nov/Dec 2019)
}

\begin{abstract}
Constantly changing shall be occur within the family's housing requirements over time, as a result of changing its scope, personnel needs, income threshold or economic conditions, or as a result of increasing technical developments, the need generated to meet these requirements, to make changes in the number of rooms in dwelling, increase or decrease, or in its uses. In that case, the family resort either to change the dwelling with another be appropriate to their needs, and this exhausts materially and socially, or to adapt this dwelling with its emerging needs. It was therefore necessary to study all aspects of housing in these countries in order to reform housing policies in order to meet all the housing needs of its users, and how to address the aspects of the housing crisis in the framework of construction, physical and urban renewal. This study shall discuss Social Housing"which is one of the most important axis of Housing" and its objectives and functional needs and types to reach the criteria to control Social Housing and dimensions that must be taken into consideration when starting to design those social housing projects.
\end{abstract}

Keywords: Housing, Social Housing, Community, Human Needs

\section{Introduction}

The housing system in the community is linked to the other systems prevailing in it. Housing is understood academically as a study of residential units in which people live and another of the practical aspect of working life, a study of the poor housing production and the desires and requirements of the people of their dwellings according to each area designated for housing on the one hand, and complementary to the other.

In all developing countries, real estate markets have experienced an unprecedented rise, which is described by a number of experts and housing owners in the crisis and has had a strong impact on them, so it was necessary to study all aspects of housing in these countries to reform housing policies in order to meet all housing needs of its users, and how to address the aspects of the housing crisis in the framework of construction, physical and urban renewal.

This study shall discuss Social Housing "which is one of the most important axis of Housing" and its objectives and functional needs and types to reach the criteria to control Social Housing and dimensions that must be taken into consideration when starting to design those social housing projects, as shown (Figure 1)

*Corresponding author's ORCID ID: 0000-0000-0000-0000 DOI: https://doi.org/10.14741/ijcet/v.9.6.1
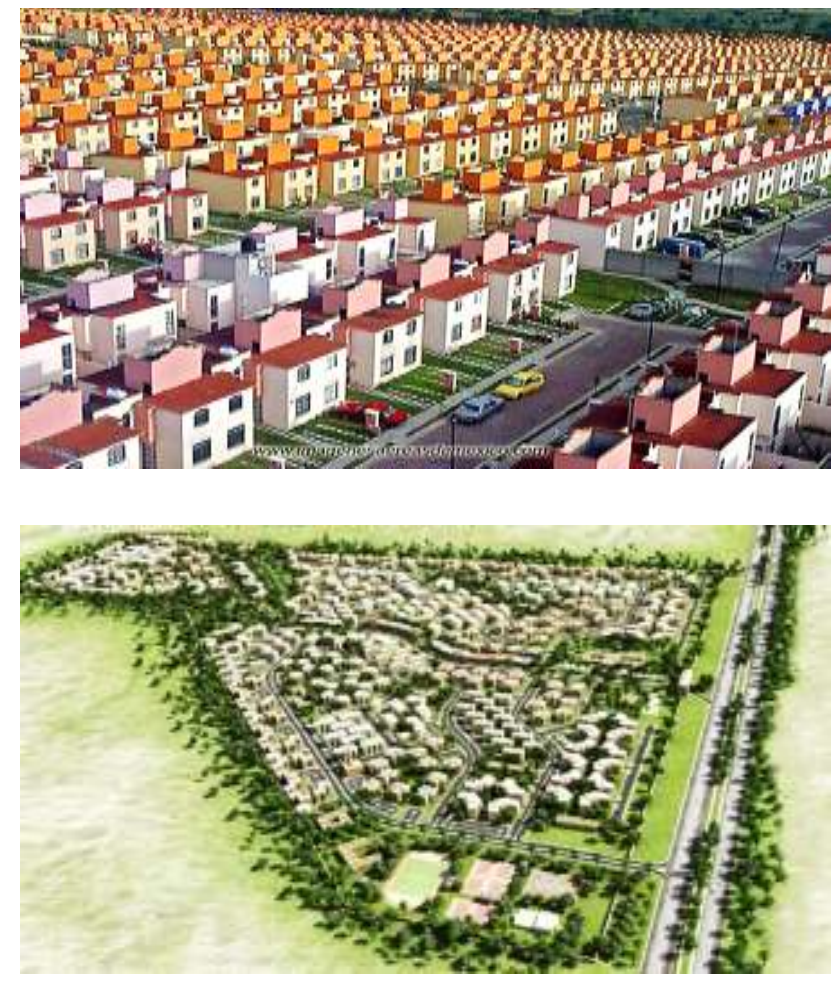

Figure 1 Some models proposed by Government Housing Organization in developing countries (Source: http:/ /xa.yimg.com/ kq/groups/ 23130753/800458094/name/HousingPrototypes.pdf) 


\section{First: Housing Definition}

Housing is generally defined as a study of residential units where people live. It is a study of the housing production market, as well as a study of people's housing needs and requirements, the problems people face in obtaining adequate housing, and the impact of housing on people psychologically, socially and culturally.

\section{Social Order}

The social system depends on the type of family system, changing the family type of the Composite or extended to the nuclear family and the stability of the new families in independent housing after living in one dwelling consisting of several floors or a wide horizontal Special parts of each family's privacy and other parts shared by all the people of the dwelling such as dining rooms or chatting and sitting places, all of this led to a change in housing system and policy in many countries of the world. As shown (Figure. 2)

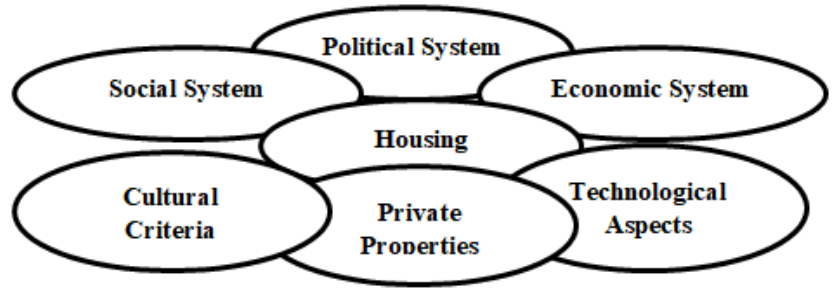

Figure 2 Correlation the housing system to other systems in society

(Source: Dr. Mohamed Aly "Flexibility in Housing - Comparative Analytical Study" Doctoral Dissertation, Cairo, 2001\}

\section{Second: Home Definition}

Housing is defined as the building that shelter human. This shelter includes all the necessities, facilities, appliance sand tools needed or desired by the individual to ensure the attainment of natural and mental health and social happiness for him and his family.

\section{The Importance of Housing}

Home is the place where human feels that he has the privacy which makes him appear in his true personality. Home is the link between man and his society. At the present time it is noticeable that family members create a kind of convergence, balance and satisfactory relationships between their basic needs and their values and housing. In order to provide housing through which to influence human behavior, it is necessary to balance the alternatives available to the different dwellings and the desires of the individuals themselves (Figure 3). The designer created a kind of convergence, balance and blocks to meet the needs of the families and their values in order to influence their behavior.
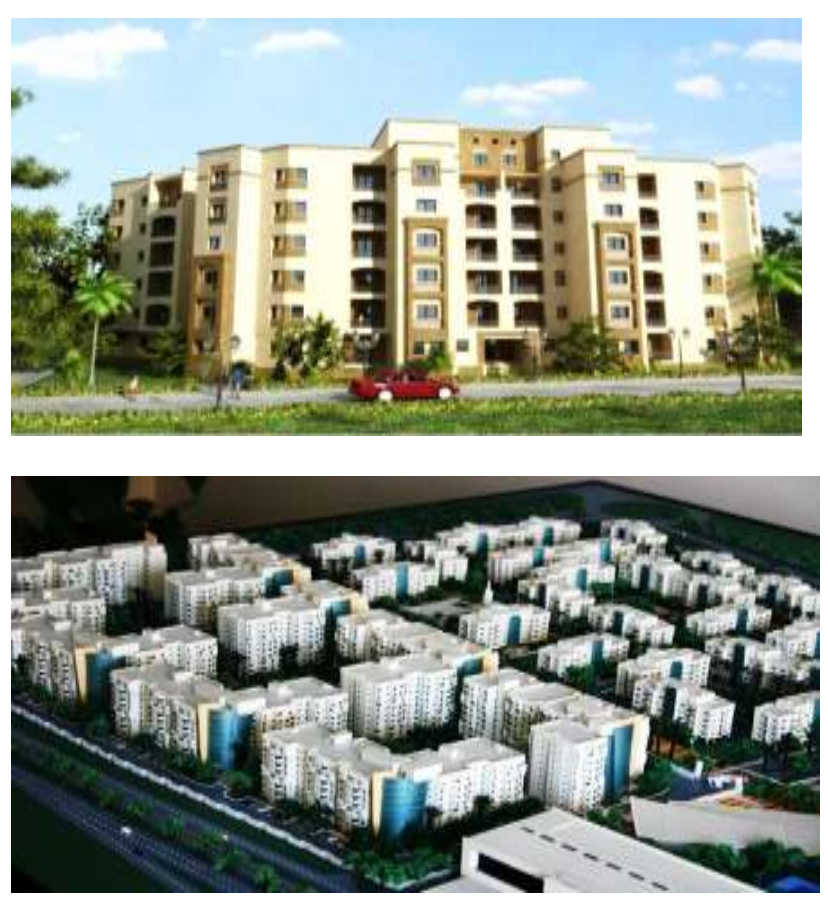

Figure 3: Models to balance between the different alternatives available housing and the desires of individuals themselves - Where the designer created a kind of convergence, balance and blocks to meet the needs of families and their values in order to influence their behavior

(Source: http://xa.yimg.com/kq/groups/ 23130753/800458094/name/HousingPrototypes.pdf)

\section{Third: Social Housing Definition}

Our social housing is considered to be all housing financed by public treasury funds, the simple definition of social housing is mainly related to tangible income of the family, which has not been able to find adequate housing under the financial circumstances of the country.

At the same time, the precise definition of social housing shall necessary clarify the various criteria that have been associated with it as mentioned bellow, in case of its absence, social housing shall lose its meaning:

1- The country's support for social housing in a sharp image and rate $100 \%$ or partial manner is mainly due to different types of social housing.

2- Social housing targets low and middle income brackets, who cannot without the country's support to obtain housing.

3- Social housing is embodied through the development of social functioning service, carried out by the housing policy in the country.

Through these three criteria, we have an integrated and accurate definition of social housing. It aims to provide suitable housing for low-income citizens and providing small family plots for construction in new urban communities for middle income brackets. It also reflects the economic and social directives that 
characterize the country. Housing types are determined as following:

- Social housing rental.

- Rural housing.

- Evolutionary housing.

- Covalent social housing.

As shown (Figure 4)

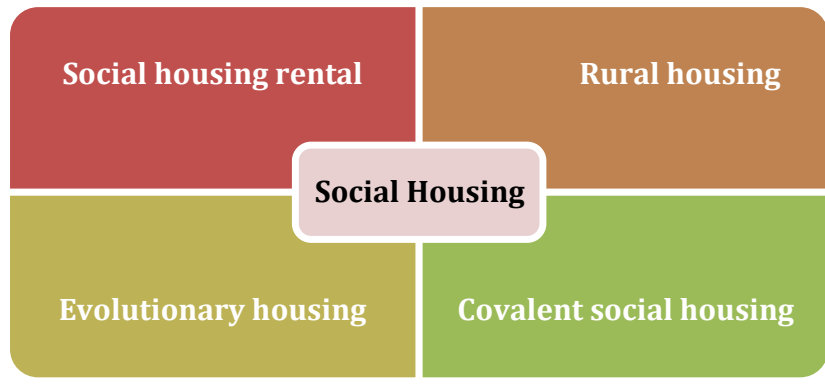

Figure 4 Social Housing Types

(Source: Arabic Planning Institute. Housing needs for Arab citizens. Kuwait)

\section{Fourth: Social Housing Specificities}

Social housing is directed to socioeconomic classes who living in difficult and random circumstances, whose financial resources do not allow them to pay high rent or to acquire housing. It is subject to a certain standard of living space (60 m2 two-room apartment) of housing at fixed prices since 1983. As shown (Figure 5)
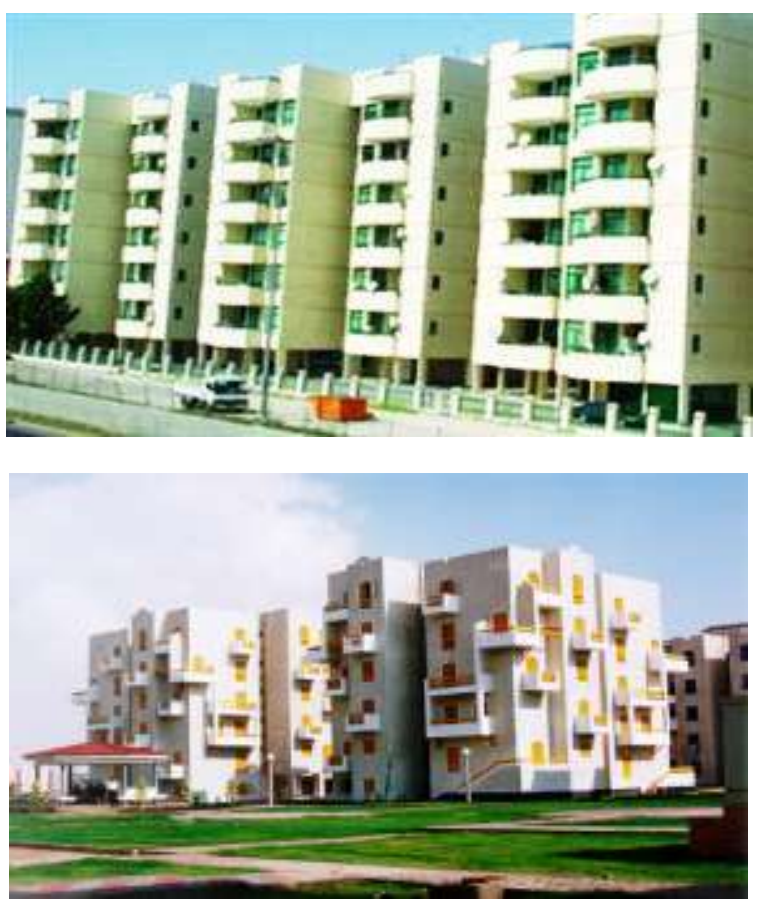

Figure 5 Social Housing Models since 1983, It is subject to a certain stereotype of the inhabited space (Source: http://xa.yimg.com/kq/groups/ 23130753/800458094/name/HousingPrototypes.pdf)
Fifth: Humanitarian Needs and Housing - Maslow's hierarchy of needs

The theory states that the minimum basic requirements Maslow's hierarchy of needs must be met and satiated before the required requirements at the higher levels as shown in Figure (6) Humanitarian Needs - Housing Needs.

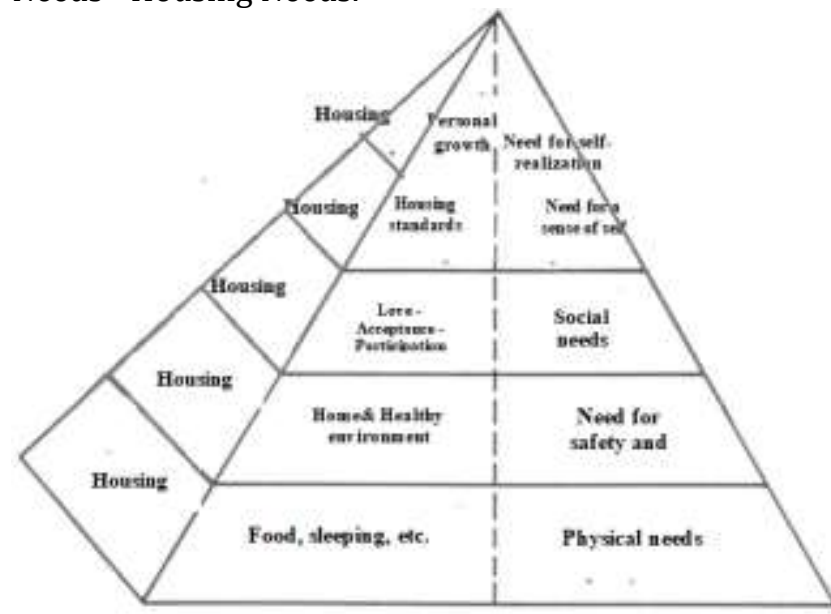

Figure 6 Maslow's hierarchy of needs and Housing (Source: Eng. Sohir Zaki Hawas

"Population needs and their impact on existing housing projects" Master Dissertation)

\section{Social Distance}

Social Distance refers to those social criteria that affect on the design and construction of the dwelling; these standards take the lead in the design and construction of the dwelling.

Planned area to meet the need of the family for construction of the appropriate dwelling

Table 1 Planned area to meet the need of the family for construction of the appropriate dwelling

(Source: Eng. Sohir Zaki Hawas "Population needs and their impact on existing housing projects"Master Dissertation)

\begin{tabular}{|c|c|c|}
\hline Item & Lengths & 5 \\
\hline Master bedroom & $4 \times 6$ & $24 \mathrm{~m}^{2}$ \\
\hline $\begin{array}{l}3 \text { Bedrooms for } \\
\text { children }\end{array}$ & $5 \times 4 \times 3$ & $60 \mathrm{~m}^{2}$ \\
\hline Living Room & $5 \times 6$ & $30 \mathrm{~m}^{2}$ \\
\hline Meeting & $6 \times 4$ & $24 \mathrm{~m}^{2}$ \\
\hline Dining Room & $5 \times 4$ & $20 \mathrm{~m}^{2}$ \\
\hline Kitchen & $4 \times 4$ & $16 \mathrm{~m}^{2}$ \\
\hline 4 Bathrooms & $4 \times 2.8 \times 1.8$ & $20 \mathrm{~m}^{2}$ \\
\hline Paths and entrances & $\% 7$ & $15 \mathrm{~m}^{2}$ \\
\hline Services & $2.5 \times 4$ & $10 \mathrm{~m}^{2}$ \\
\hline Buildings & $\% 5$ & $11 \mathrm{~m}^{2}$ \\
\hline Total & - & $230 \mathrm{~m}^{2}$ \\
\hline
\end{tabular}

The total area is divided into two floors with a floor area of $115 \mathrm{~m} 2$. This area plays a large role in the construction of an economic dwelling that meets the needs of the family from the appropriate area. 


\section{Sixthly: Social aspects of the housing process in social housing: as shown (Figure 7)}

- Population needs

- Functional needs

- Social / Psychic needs (Hygiene / Civilization)

- Economic needs

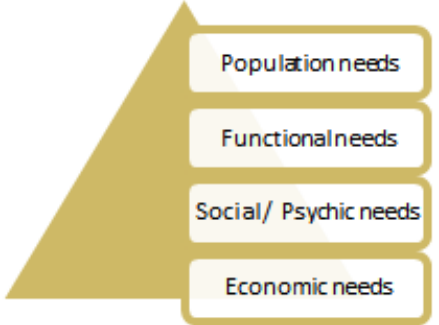

\section{Social aspects of the housing process in social housing}

Figure 7 Social aspects of the housing process in social housing (Source: about researcher)

\section{Population needs}

In order to meet the need for adequate housing, the buildings shall be considered the following:

1. The buildings' height and its relation to the width of the street and the roads surrounding it.

2. Residential buildings need to have the highest possible privacy for the population, an element that cannot be overlooked at design.

3. Security is considered one of the most important elements by an escape stairway in multi-unit buildings or high altitudes.

4. The space is the percentage of the cube built for the total population and the proportion of each person "the normal range between 4.65 to $8.50 \mathrm{~m}$ at least".

5. Direct the buildings to take advantage of the wind and avoid unwanted wind, at the same time make use of the sun as much as possible in cold weather and protect the dwelling from rain.

6. Facilities availability (Water - electricity sanitation).

7. Ventilation is necessary for each room for housing enjoys sufficient degrees of lighting and ventilation.

\section{Functional needs}

Where home function as a shelter, what means protection from weather conditions and environmental surroundings.

The dwelling must provide protection from theft / attacks / ....

In addition to variety of activities and functions that must be provided by dwelling (sleeping / studying / eating / preparing food / seating and reception of visitors / ...).

\section{Social / Psychic needs}

Variety of needs related to socio-cultural and cultural factors. These needs vary among communities and population groups within the same community.

\section{Example}

- Kitchen: American system opens on space.

In Egypt (Rural): Cooking takes place through an outdoor patio

In Egypt (Urban): Closed kitchen to achieve privacy

- Bathtub: If the farmer lives in an ordinary unit, the bathtub will be used for raise birds, ducks, or dough. Therefore, we find a close correlation between the functional and social needs and their impact. Therefore, the social aspects and the cultural backgrounds must be taken into account for the quality of the population required for habitation.

\section{Psychic needs}

Self-expression and a sense of privacy, uniqueness and security

Attention to it is very important and is reflected on the functional aspects even in housing low-income.

\section{Example}

If the owner of a fruit shop gets more income from a university graduate, the owner of the shop does not care about the location of the housing unit, but it must be a large area and fully furnished to prove the physical capacity and self-proof, but the university graduate needs a small housing unit provided that they are in a respectable and express Itself and its status. For example, make changes in the facade to achieve self and uniqueness in the work of different colors or configurations.

\section{Economic needs}

Most important farness is the family ability to afford the cost of housing without affecting on the cost of other aspects of life. Housing may be a means of increasing income.

\section{Example}

Provide a place in the house used as a sewing project, for example, where the head of the house rents part is employed as a shop or lawyer's office. The house can be used for the future if it is inherited to the children and grandchildren according to the type of possession (ownership / rent). Therefore, the Tenancy Law (1960s), which does not specify And therefore the owner cannot leave the house and even after the 
amendment of the law is inherited from the housing unit of the resident with the original resident for two years before death.

\section{Seventh: Types of social housing}

\section{1- Developmental Housing}

Core House that emerged in the late seventies and early 1980s in the Arab Republic of Egypt, which is one of the first Arab countries that suffer from the problem of lack of housing and the low efficiency of existing ones, especially in densely populated residential areas and low incomes. Which assist in the provision of housing such as construction of temporary housing, giving grants and convenience loans which contribute to programs that help in the provision of housing by self-help, but these methods did not achieve their objectives in full (and applies to most countries that suffer from the problems of (2). The idea of Core House (Figure 2), which partially helps to achieve economic housing, and depends on the gradual construction and self-help of the population and commensurate with their intermediate needs as shown (Fig. 8).

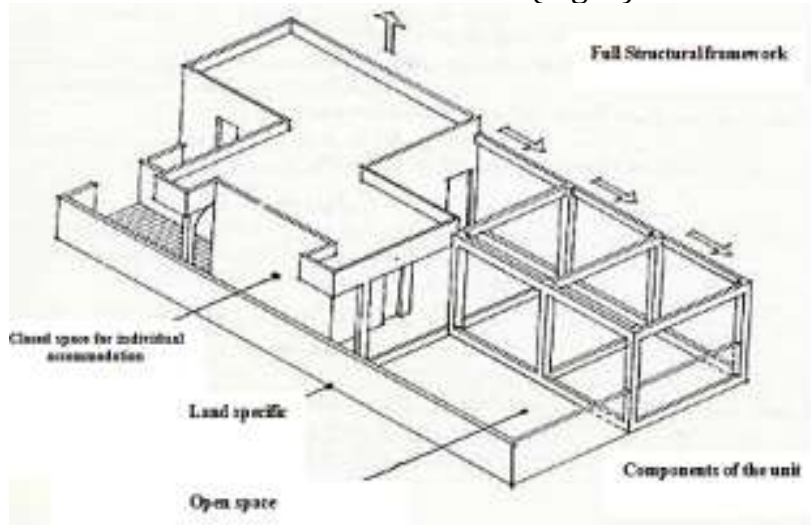

Figure 8 Core House

(Source: Ibrahim Hazem (1984) A study to provide housing for lowincome people in the Islamic community, Seminar on Housing in the Islamic City, Center for Planning and Architectural Studies, Cairo,

\section{Characterizing} Egypt)

1- The minimum home is given so that the population can move directly to it.

2- The facilities shall be extended to each plot.

3- It can be just an outer wall and people inhabit a tent inside it until the house be build.

4- It can be empty concrete structure for room, bathroom and kitchen.

5- It can be a room + bathroom or 2 rooms + bathroom.

The country gives the final shape of the dwelling. But they did not support it. For example: 10th of Ramadan - Sadat cities.

\section{Disadvantages}

1- These projects did not impress the officials for its inappropriate form (not glamorous), it's planned but not divided from inside.
2- For the success of these projects we need to have small architects residing in the project with the population to guide them during the construction process.

In Tunisia: the architect lives with the population to guide and help them.

In Egypt: the output is much similar to random housing.

\section{Advantages}

- This kind of interim development is not being taken over by the country.

- The state is only making a network of facilities and roads (Technical works) that cannot be left to people.

\section{2- Old rural housing}

Basic functions of rural housing

Over the years, the Egyptian farmer has been able to develop his residence until he finally got a home that achieved most of the functions he saw as essential. As:

- Protection from natural factors

- $\quad$ Providing security and protection from thieves and enemies.

- Providing social protection and privacy.

- Providing suitable places to perform life functions.

Description of the old rural housing

- Entrance to the house

- Guesthouse or Mandara

- Central courtyard (inner courtyard).

- Rooms

- Winter room

- Animal barn

- Milky Way

- Stairs

- Roof

- Bathroom. As shown (Figure 9)

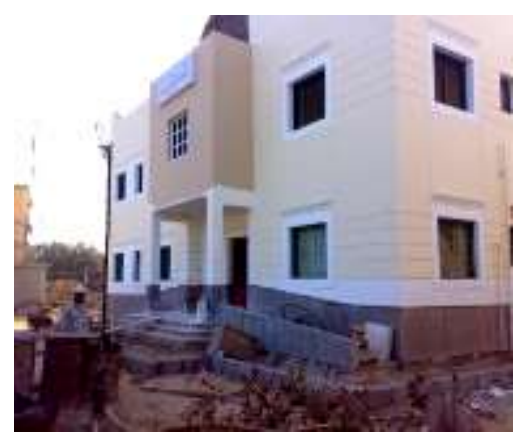

Figure 9 It illustrates the horizontal homestead of the old rural housing and its façade (Source: about researcher)

Example: Qurna village (Hassan Fathi) the unit was a repetitive buildings surrounded by a vacuum between the purpose of achieving privacy. As shown (Fig. 10) 


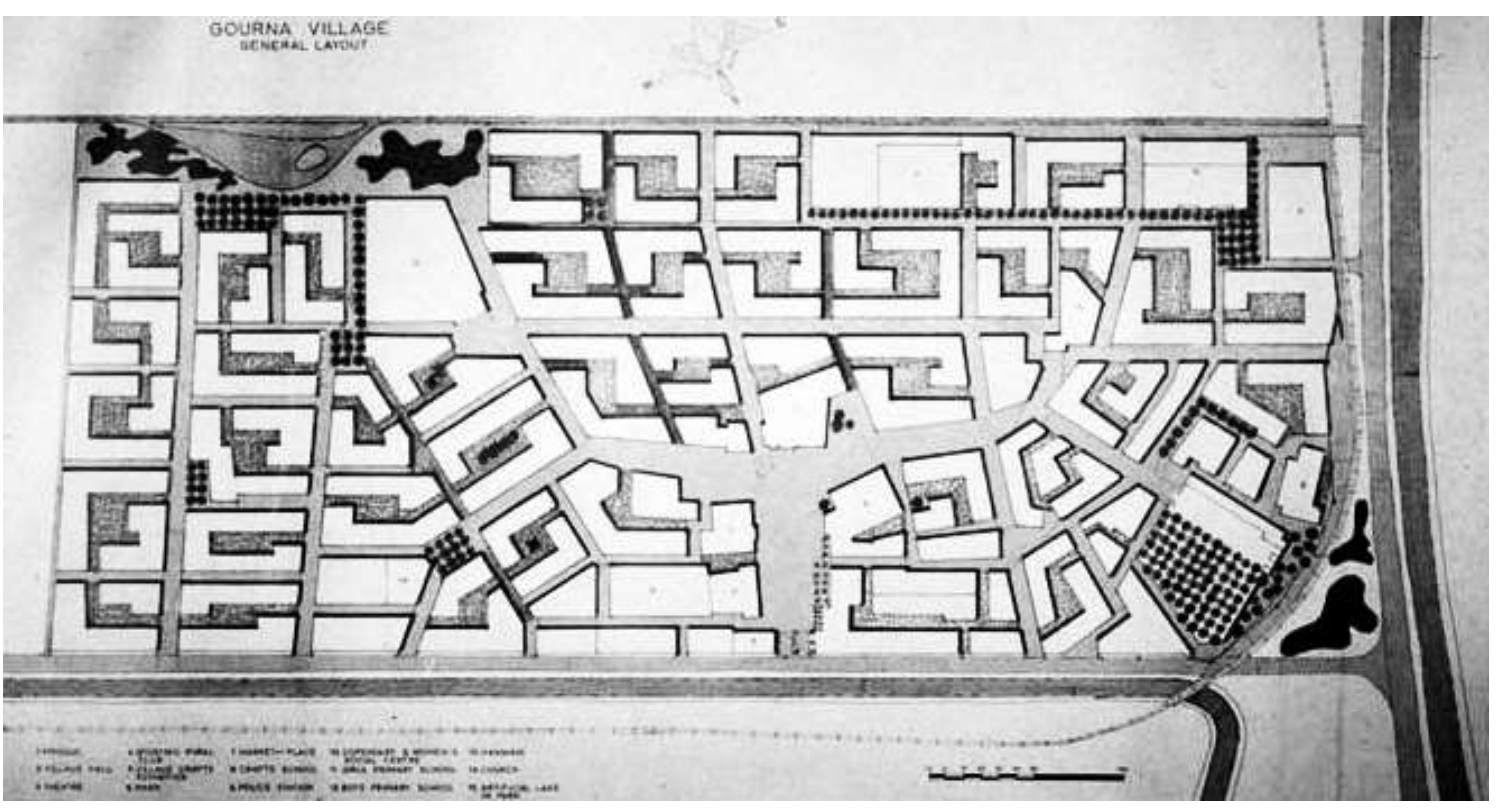

Figure 10 General Location Planning the village of Qurna in Luxor is an example of rural housing, the unit was a repetitive buildings surrounded by a vacuum between the purpose of achieving privacy

(Source: Dr. Abdulbaky Ibrahim “How the resident completes his own dwelling”Magazine of the World of Construction Issue No. 2 April 1980)

\section{Modern Rural Housing}

A change has occurred in the style of buildings, the materials used and the design, including the general shape and appearance of the building and spaces inside the dwelling and its functions. A new social structure has been created that works in many areas besides agriculture. Many modern buildings in the countryside,

\section{Components of modern rural housing}

The modern rural residence is often composed of three rooms and a hall. It is characterized by the provision of the necessary elements such as the living rooms, bathroom and the kitchen, as well as other elements such as the staircase, guest room, internal skylights and fountains etc., as shown (Figure 11)

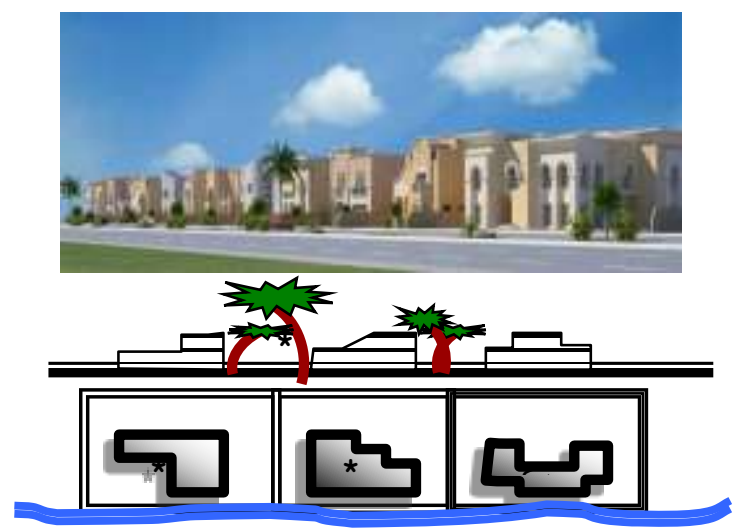

Figure 11 Examples of rural housing in which there is a change in the style of building, materials used and design, including the overall shape of the building (Source: Dr. Abdul Baki Ibrahim, "How the inhabitant completes his \her own house" World of Construction Magazine No. 2- April 1980)

\section{2- Social housing}

Social housing contribution is a housing program directed at middle-income for the Middle class groups for acquisition a house based on a joint financial structure between the beneficiary and the State subsidy. As shown (Fig. 12)
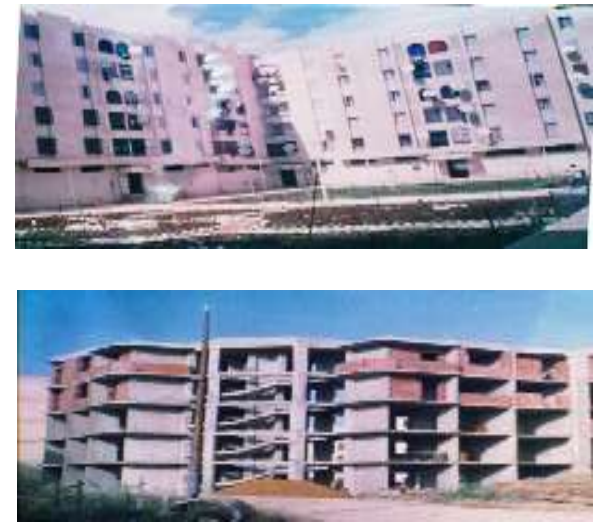

Figure 12 Models of social housing in Egypt (Source: Dr. Abdul Baki Ibrahim, "How the inhabitant completes his \her own house" World of Construction Magazine No. 2- April 1980)

\section{Financial Structure of Social Housing}

1. Personal contribution: The contribution of the beneficiary is individual and varies according to the actual cost of housing. The cost should not exceed the statutory limit of 2,000,000.00 EGP or four times the state subsidy.

2. Contribution of the State (State subsidy): This contribution is also variable according to the income of the beneficiary and ranges between 40,000.00 EGP and 
500.000.00 EGP according to the ministerial decision dated on 15 - 11 - 2000.

\section{Pros and advantages of this type of housing}

Possession of ownership - housing. / The scope of completion does not exceed 12 months. Apartment description (2- bed room - 3 bed rooms - 4 bed rooms). As shown (Fig. 13, 14)

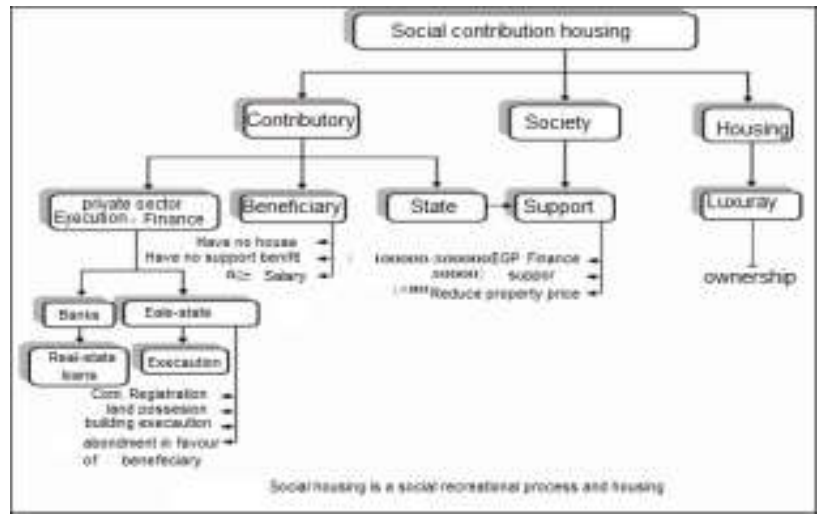

Figure 13 Models of Financial Structure of Social Housing in Egypt

(Source: Dr. Abdul Baki Ibrahim, "How the inhabitant completes his \her own house" World of Construction Magazine No. 2- April 1980)

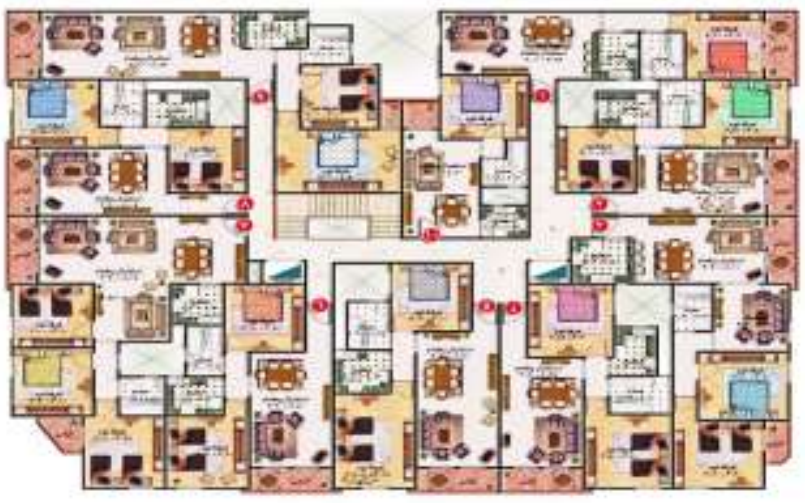

Figure 14 Models of horizontal projections of social housing

(Source: Dr. Abdul Baki Ibrahim, "How the inhabitant completes his $\backslash$ her own house" World of Construction Magazine No. 2- April 1980)

4. Rental housing

- Flexibility in pricing, financing and best real-estate loans

-Units for rent less than (40 square meters)

Advantages:

Ideal solution for young people, very low price. *

Defects:
- Not refundable. As shown (Fig. 15)

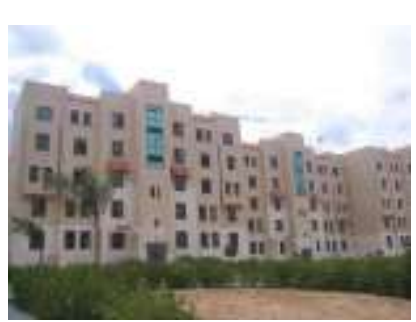

(A)

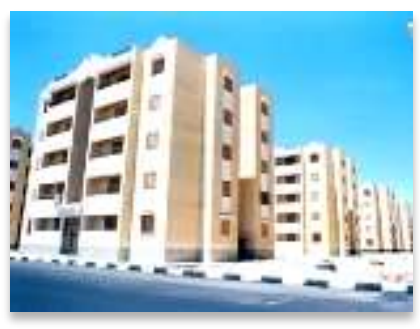

(C)

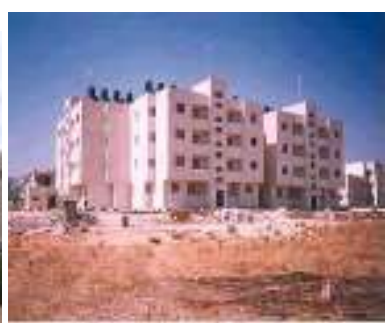

(B)

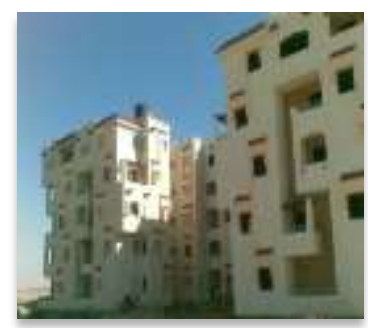

(D)
Fig. 15 A, B, C, D Models of rental housing and how to access the buildings and its blocks density in the areas of land with commitment to the flats of housing units

less than 40 square meters (Source: The Researcher)

\section{Eighth: What should be considered when designing the housing unit in the social housing}

There are many methods that the designer must follow in order to develop social housing and meet the requirements of the population, so this study clarifies those methods which the designer should take into consideration before starting the design; are as follows:

1. The ideal way in the land division and the appropriate direction of building. As shown (fig. 16)

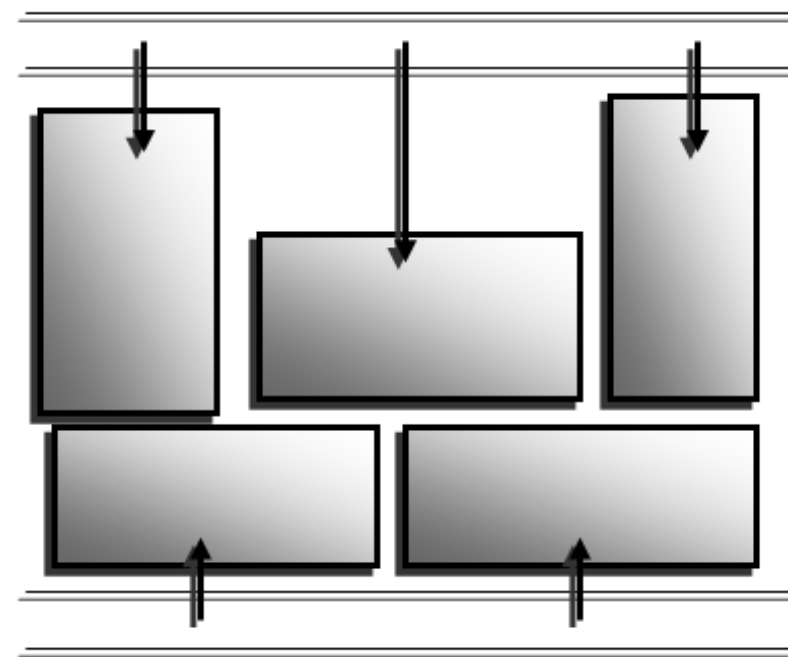

- Great loss and heavy costs on the state

(A) 


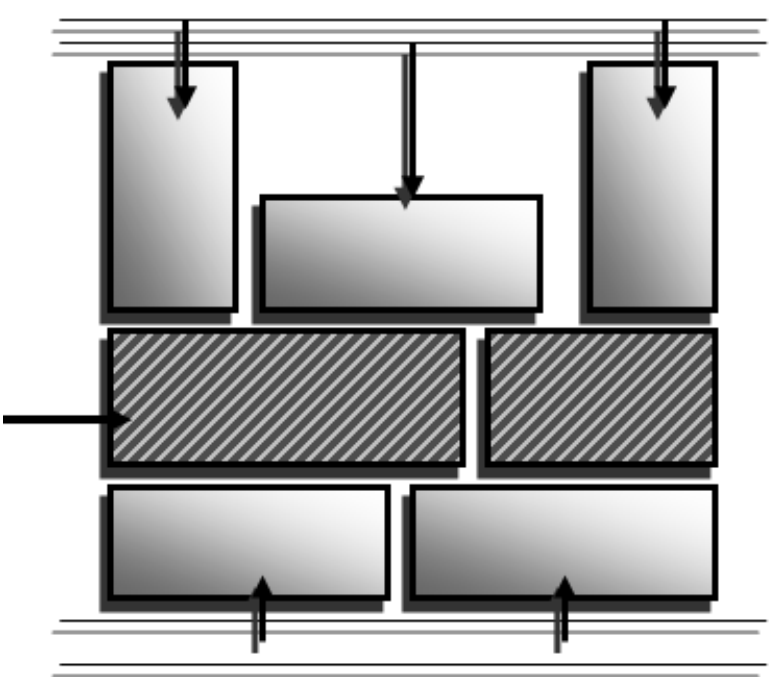

Fig. 16 a, b Application of the best method of land division to determine the location and direction of the building, to avoid the high cost, and focus on the importance of accessibility and privacy (Source: The Researcher)

2. The designer is required to take into consideration the models of housing units' evaluation when designing the social housing, either on the horizontally or vertically projections levels, in order to reduce the costs and meet the housing needs of its users; as shown (Figure 17).
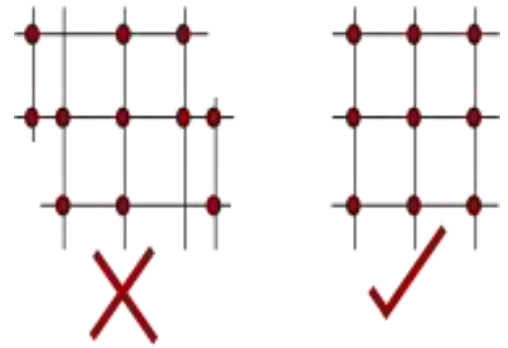

(A)

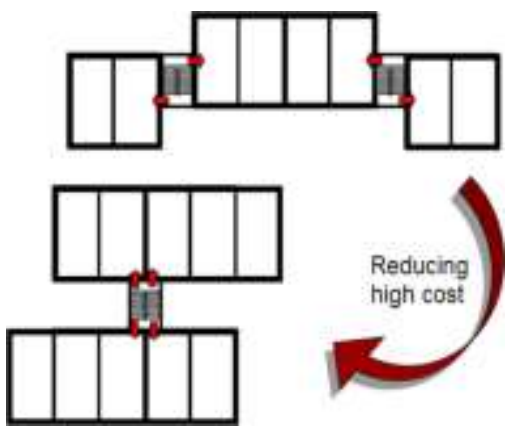

(B)

Figure 17a, b Evaluation models of the housing unit when designing the social housing, whether on the level of horizontal or vertical projections or traffic movements as well as construction to reduce the cost and meet the housing needs of its users always.

(Source: The Researcher)
3. Simplicity in design and avoidance the complex designs, which require special skills and materials while keeping the suitable apartment area and the appropriate housing by providing the necessary spaces. As shown (Fig. 18).
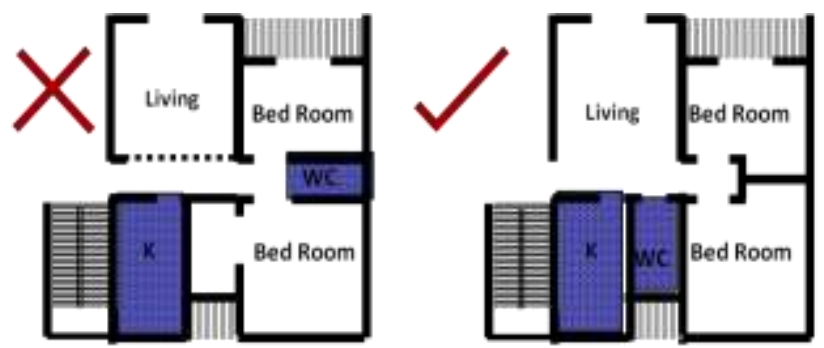

(A)
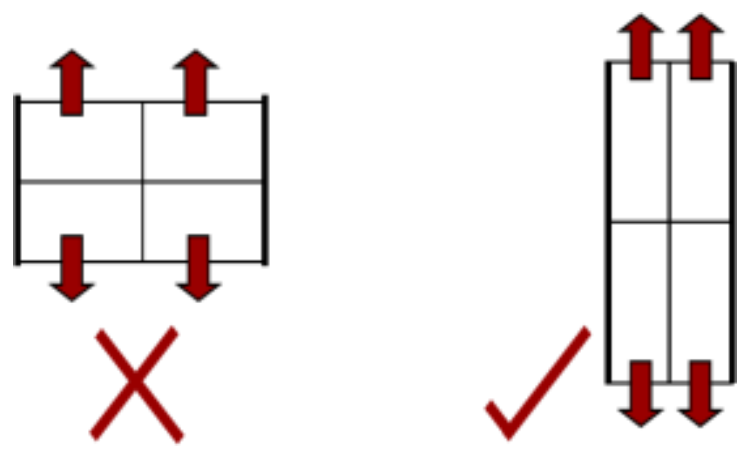

(B)

Figure 18a, b Simplicity in design and avoidance the complex designs, which require special skills and materials while keeping the suitable apartment area and the appropriate housing by providing the necessary spaces (Source: The Researcher)

4. Reduce the facades always of social housing in order to minimize the costs and meet the housing needs of its users; as shown (Figure 19).

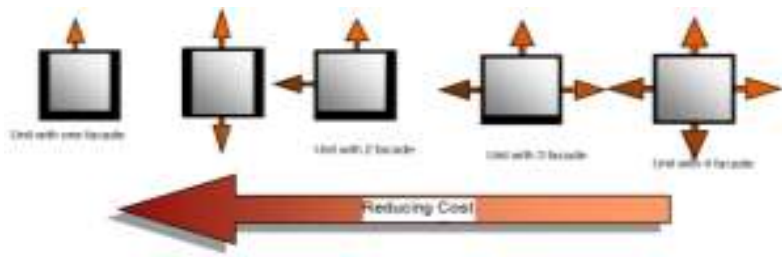

Figure 19 Facades reducing of social housing in order to minimize the costs and meet the housing needs of its users (Source: The Researcher)

Ninth: The standards and dimensions that must be taken into consideration in the design of the social housing.

After examining the development of social housing and its various stages, the designer must apply the criteria and dimensions that must be taken into consideration in the design of the social housing as shown (Figure 20). 


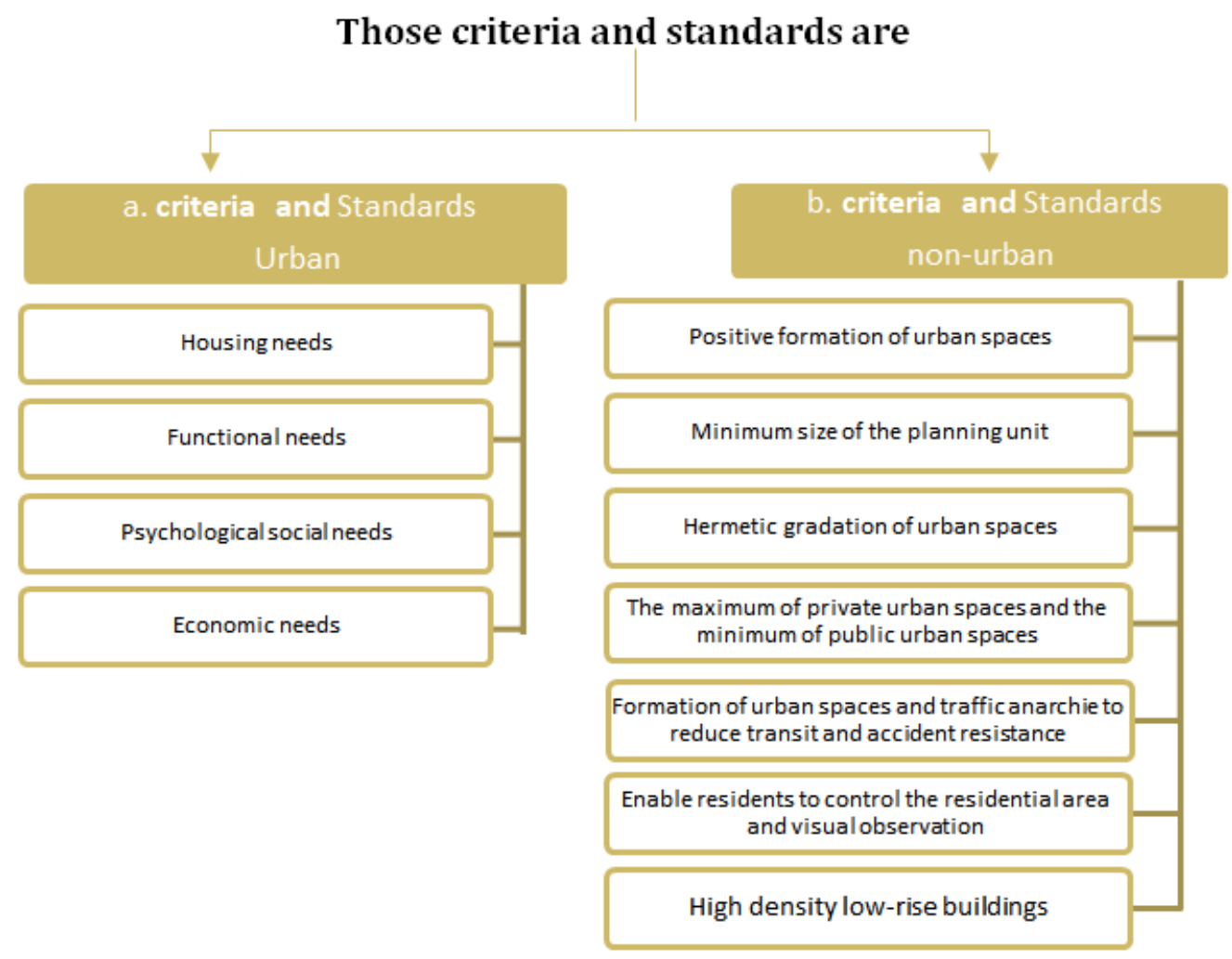

Figure 20 The standards and dimensions that must be taken into consideration in the design of the social housing (Source: The Researcher)

\section{Tenth: Conclusions and Recommendations}

Through the previous review of the development of social housing, after identifying the most important factors affecting the housing development where it is possible to develop the following methods, which will help to provide social housing, which are divided into the following:

\section{First: Methods controlled by the official authorities are include the following}

1. Apply the best method of land division to determine the perfect location and direction of the house, to avoid costly site processing, and focus on the importance of accessibility and privacy.

2. Controlling the land area to be not more than 300 $\mathrm{m} 2$ in order to ensure the optimum utilization of the appropriate housing for the needs of the family from the housing spaces, and to ensure that the building rate does not exceed $40 \%$ of the land area for the private housing.

3. Developing the necessary regulatory, financial and legal abilities, foundation and institutions to implement ongoing efforts to develop and support housing.

4. Creating legislative frameworks and financial foundation that would enable the public and private sectors (official and non - official), municipalities and families to contribute to the production of housing units for those in need of housing or to improve the housing conditions of those who have already houses, according to their needs and priorities.
5. Evaluate the progress of the national housing strategy and the programs included therein in order to strengthen the positive aspects in it and to correct the negative tracks that may come out when it will be applied.

\section{Second: Methods controlled by the designer and developer are include}

1. Simplicity in design and free from complex designs, which require special skills and materials for implementation while maintaining the size of the appropriate housing by providing the necessary spaces for users.

2. Flexibility and dependability on the stages of construction in accordance with the family conditions and focus on the vertical expansion of housing.

3. Dependence on the system of carrier walls in the construction of small houses, and the use of local building materials and finishing materials are known and appropriate to its environment and do not require continuous maintenance.

4. Housing development within structured urban patterns consistent places of workers regrouping, social requirements and the structure of residential areas.

5. The cost of housing are suitable for low income groups should be commensurate with the potential of individuals or families who will rent or own this type of housing.

6. The designer should take into consideration always the models of evaluation of the residential unit in the 
design of social housing, whether on the level of horizontally or vertically, in order to reduce the cost and meet the housing needs of its users.

7. Dependence on natural lighting and ventilation by regulating the placement of the openings in the appropriate location and suitable areas, with possible use of traditional ventilation towers if possible.

8. Ensure that housing sites for the poor groups are close to places or linked to transportation that does not raise the cost of actual housing.

9. Apply standards and dimensions that must be noted where designing social housing.

10. Simplicity in the interior design and selection of simple and appropriate furniture and rely on furniture easy to move and maintenance.

11. Choosing the right contractor, which helps to reduce the cost of construction, and provide the highest quality of construction and finishing work by responsibility of good developer in materials supply.

\section{References}

1. Abdul Baki Ibrahim (April 1980), "How the inhabitant completes his $\backslash$ her own house" World of Construction Magazine No. 2

2. Suheir Zaki Hawas, "Population Needs and their Impact on Existing Residential Projects" Master Thesis

3. Laila Ahmed Muharram (1990) "Indicators and manifestations of random areas growth of urban communities" Symposium on the protection of the environment and legal housing

4. Milad Hanna "Housing and the trap - problems and the solutions" Arab Future House - Cairo

5. Mamdouh Al-Wali, "Residents and people of "Slums and random areas" - a study prepared by the Engineers Syndicate - Egypt "
6. Mohamed Ali (2001) "Flexibility in Housing Theory and Practice" PhD thesis, Cairo

7. http://xa.yimg.com/kq/groups/23130753/800458 094/name/HousingPrototypes.pdf

8. Arabic Planning Institute. Housing needs for Arab citizens. Kuwait.

9. Understanding Slums (2003) The Challenge of Slums- UN Globule report on Human Settlement UN HABITAT

10. Ghada M. Reihan (2000)Improvements of the slums and random areas in the effectiveness of the implementation of the plans - Master Thesis Department of Architecture - Cairo University.

11. Azza Amin Sri(1989) Rural areas contained in Urban communities - Comparative analytical study Master Thesis - Department of Architecture - Cairo University.

12. Amr Mohamed Al-Zawahri (1991)Rural Communities within Cities with Special focus onthe Greater Cairo - Master Thesis - Department of Architecture - Cairo University 1991.

13. Parkin, E. and Wilson, W. (2016a) Social housing: The end of 'lifetime'

14. tenancies in England? House of Commons Library briefing Number 07173, 27th May.

15. Parkin, E. and Wilson, W. (2016b) Comparison of Right to Buy in England, Scotland, Wales and Northern Ireland House of Commons Library briefing Number 07174,13 th July.

16. Pearce, N. and Taylor, E. (2017) 'Government sending and welfare' in Park,

17. A., Bryson, C., Clery, E., Curtice, J. and Phillips, M. (eds.) (2013), British

18. Social Attitudes: The 30th Report, London: NatCen Social Research.

19. ONS (2017) Statement on classification of English housing associations

20. https://www.ons.gov.uk/news/statementsandlette rs/statementonclassificationofenglishhousingassoci ationsnovember2017 November, Last accessed January 2018. 